Branko Mihailović ${ }^{1}$

Zoran Simonović ${ }^{2}$

Radojica Sarić ${ }^{3}$

Institute of Agricultural Economics, Belgrade
ORIGINAL SCIENTIFIC ARTICLE doi:10.5937/ekonomika1604055M

Received: November 21, 2016

Accepted: December 06, 2016

\title{
NATURE AND CHARACTERISTICS OF MANAGEMENT CONSULTING IN SERBIA ${ }^{4}$
}

\begin{abstract}
Given the current trends in the consulting countries of our region, as well as the degree of development of guidelines consulting with EU countries, the market for consultancy services in Serbia has not been significantly developed in the past. Owners and managers of companies are still not enough to feel the need for external services, which would solve business problems. Bearing in mind the level and quality of demand, not offer to consult services has not reached the required level. Accordingly aim at this paper is to examine the nature and developmental aspects of management consulting in Serbia in the transformation of the economy towards market business model. The research results show that the development of the market of consulting services is not a simple or easy task that can be accomplished in a short period and with modest financial contribution to the country. Local private consulting sector often lacks not only an interest in this area, but the real capacities, and entrepreneurs are willing to spend their time and money only to services from which they can see direct benefits in a very short period of time. In such circumstances, private market these service can hardly be generated independently.
\end{abstract}

Key words: consulting, development factors, education and awareness, affirmation of market economy.

JEL Classification: M21, M54

\section{ПРИРОДА И КАРАКТЕРИСТИКЕ МЕНАЏМЕНТ КОНСАЛТИНГА У СРБИЈИ}

\author{
Апстракт \\ С обзиром на актуелне трендове консалтинга у земљама нашег региона, \\ као и степена равоја консалтинга у земљама ЕУ, тржиште консултантских

\footnotetext{
${ }^{1}$ brankomih@neobee.net

${ }^{2}$ zoki@medianis.net

${ }^{3}$ radojica_s@iep.bg.ac.rs

${ }^{4}$ This paper work is result of the project No. 46006 - III „Sustainable agriculture and rural development in function realizing strategic goals of the Republic of Serbia in framework of Danube region", financing by the Ministry of Education and Science of the Republic of Serbia.
} 
услуга у Србији није се у значајној мери развило у протеклом периоду. Власници и менацери предузећа још увек довољно не осећају потребу за екстерним услугама, којима би решили пословне проблеме. Имајућу у виду степен и квалитет тражње, ни понуда консултантских услуга није достигла потребан ниво. Сходно томе ииль рада је да се сагледа природа и развојни аспекти менаимент консалтинга у Србији у условима трансформащије привреде ка тржишном моделу пословања. Резултати истраживања показују да развој тржишта консултантских услуга није ни једноставан ни лак задатак који се може реализовати у кратком року и уз скроман финансијски допринос државе. Локалном приватном консултантском сектору често недостаје не само интерес за ову област, већ и реални капацитети, а предузетници су спремни да потроше своје време и новач само на услуге од којих могу да виде директну корист у веома кратком временском периоду. У таквим околностима приватно тржиште ових услуга тешко да може самостално да се генериме.

Кључне речи: консалтинг, фактори развоја, образовање и информисаност, афирмација тржишног пословања.

\section{Introduction}

Management consulting is one of the most important management techniques developed over the last fifty years. The secondary effect of this invention is the rapid development of new frameworks, tools and techniques in a number of companies. Surprisingly, however, this appears not much to write. Partly this is due to the small number of people interested in this subject - is still to be seen as the inability of a large number of managers to recognize the benefits of the services of consultants (Kubr, 1976). In other work, this may be due to the fact that the consulting company is very secretive and discreet, and therefore their activites is difficult to analyze and explain. Creating attractive business enterprises initiated the need for consulting. Consulting organizations helps companies to achieve their goals, solve problems related to business and management, to identify and exploit new opportunities, increase their knowledge and put into practice the proposed changes. In the domestic economy, a lack of knowledge in the field of business planning, which is essential for the opening of small and medium-sized enterprises. The essence of the necessary changes can be defined as a new entrepreneurial society that encourages risk-taking and creating new entrepreneurial skills. Consulting services is the professional assistance in establishing businesses, but also in the identification, diagnosis and resolution of problems relating to different areas and aspects of the business and enterprise management (Mihailović, 2007).

In our conditions the goal of consulting is to increase the level of business efficiency, which is one of the key factors of successful change in a profitable business. The dominant model of consulting, which in our practice is a combination of expert and models Doctor - patient. Process consulting is still unknown in the national consulting practice. The most common domestic leaders ordered a study on the development strategy and organizational design on which to engage teams of consultants (Janićijević, 
1992). The consultant must be competent, informed, objective, and in many cases, a good psychologist, in order, through dialogue with the employees in the company, pronikao of the problem. There is a tendency to standardize activities of consultants, to a recipe that has proven successful applied in all situations. This of course makes the business consultant, but the main question: Is such a problem-solving approach produces results? (Mihailović, 2007). One successful solution should not be generalized and applied to the forthcoming engagement.

\section{The concept and importance of management consulting}

Consulting is often defined as "a service provided by an independent and qualified person or persons in the determination and Investigations issues concerning policy, organization, procedures and methods, recommending appropriate activities and assisting in their implementation" (Guide to membership, 1974). The definitions used by other professional associations with management consultants, such as the Association of Management Consulting engineers in the US are very similar to this. In all of them management consulting is a special service to which managers can call if they need to obtain help in solving any problems. Consultancy work starts from conditions that are considered to be unsatisfactory, and which, according to expert estimates, can be repaired; ideally, ends with what is perceived as an improvement (improvement, refinement). Some specific features of management consulting should be noted at the outset of this study (Kubr, 1976).

First, consulting (counseling) is an independent provider. However, this independence is limited by the fact that consultants are entering into a very complex relationship between their client organizations and people who work in them. Basically, the consultant team is added to the existing organization that asks for help, where his capacity additions at the same time its main role. The consultant has no direct authority to decide on the changes and apply them - but this should not be considered as defects. He needs to master the skill of deep consideration changes of giving up their independence. So firstly ensures the highest level of involvement in the work of the client, so that ultimate success is shared success.

Secondly, consulting is essentially advisory services, which means that you do not hire consultants to manage organizations or to make delicate decisions on behalf of desperate managers. They are advisers (advisers) and their responsibility is to the quality and validity of the advice given. It is not just about giving the right advice, but also about giving advice at the right time and in the right way - these are basic skills consultant. Of course, in practice there are many variations on consulting and many degrees of "consultation". The client in turn has to be very active in the process of receiving advice arising from the consultant, trust them, and adopt as their implementation in your organization, because, ultimately, they bear full responsibility for the consequences of which are still there.

Third, consulting is a service that provides professional knowledge and skills that are essential for the practical solution of the problems of management (administration). An individual becomes a management consultant in the full sense of the word accumulation of knowledge about the different situations of management and organization and the 
adoption of the necessary skills for problem solving - to determine the problem, finding relevant information, analysis and synthesis (assembly and disassembly information), choosing the right solution when there is a larger number possible, communicate with people and so on. What is special to consultants is that over the years, going through a number of organizations and learn how to use their accumulated experience of previous assignments to the new conditions. In addition, professional consultants are constantly trained in methods and techniques of management, including those that are used at universities and in research Institution's; convey this experience of customers and help them in the implementation. They work as a link between theory and practice in management. It is understood that managers must also possess certain types of skills, especially in the implementation of new ideas.

Fourth, not a consulting service that provides an easy and simple solution is too severe management problems. It would be a mistake to view consultants as a wizard that can help you in all situations. Consulting is hard, systematic and disciplined work based on solid analysis of facts and research of all possible solutions. Strong management commitment to solving the problems of organization and cooperation between the client and the consultant are of equal importance to the quality of the advice being received and for outputting.

In today's conditions, when all services are primarily oriented to the user, is important to measure their level of satisfaction. The consulting firm can hardly continue its successful business without the continuous improvement that is achieved by using the data obtained from the analysis of user requirements and their positive regimen. It is important to consider the different types of users that are associated with the project. Three types of users exist on almost every aspect of consulting intervention (Philips, 2000). In short, customer satisfaction is the key of success and can be achieved in various ways that focus on success is getting early feedback is essential. Otherwise, projects can easily slip from the planned and designated times. Also, one should never rule out the possibility that the project does not comply with the outset that the selected project is sometimes a bad solution to a specific problem, it is necessary to find out at an early stage of its implementation, in order to enforce the timely correction and thus prevent the occurrence of weather misunderstanding, misinterpretation, poor communication, etc.. If corrections are insufficient or impossible, poorly defined project can be replaced by a better, more efficient easily and quickly before it comes to more serious problems.

\section{Forms and methodology consulting}

In modern conditions competitive success of the company depends primarily on its ability to hire and effective use of their intangible resources, the ability to quickly adapt to ever-changing environmental conditions and other pre recognize and meet the constantly changing needs and requirements of consumers (Gajic, 2004). Consequently, consulting developed as external and internal services (from the aspect of the organization which uses consultants).

An external consultant is administratively and legally totally independent of the organization for which he works. Internal consultant is part of a special working unit enterprises - companies, groups of companies, government ministries, etc.. The precise 
boundary to these two types is difficult to withdraw - an autonomous consulting bureau that helps the minister for the economy can be regarded as an internal unit as it is part of government services, but can have the same working relationship between public companies as well as independent external consulting firms. In practice consulting organizations of the public and private sectors and the use of internal and external consultants (Bols, 1971). Internal consulting services are often considered a better solution to problems that require a deeper understanding of a very complex internal relations, procedures and political factors in large organizations because of the presence and awareness of the different functions of the organization or the specific limitations which affect the business. If there is a constant demand for advice related to special methods and techniques, internal consulting service can be cheaper and more productive. However, eskterni consultants are better even in organizations that have internal consultants when these workers do not meet the internal criteria of impartiality and confidentiality or have no knowledge of certain areas. In some cases, complex tasks are delegated to the external and internal consultants, or from internal consultant may be required to precisely define the tasks of external consultants and to cooperate with them with the aim to learn as much as possible about the things that are resolved.

Basic principles and methods of consulting apply equally to the activities of external and internal consultants. As for the specific management functions and techniques that will engage consultants, this profession has gone through several stages of development. During the twenties of the last century a number of consultants in the United States began offering services primarily in the areas of production - in research work, production planning and rationalization. The next big area that they faced was accounting. Consulting in the general area of management (management) was associated with questions about structure and procedures. In the postwar period, consulting with marketing, and also in various recent managerial techniques, operations research and system design, he began to develop rapidly. At this point the profession could not claim to provide a complete set of consulting services. After this, there has been a rapid expansion and changes from the general concepts of consulting management problems by adopting the perspective of business strategy, long-term planning, decision-making, and more recently, the development of the organization.

A significant problem of the field of training and development, present for years, is the lack of transfer of learned knowledge. In many situations the acquired knowledge is not transferred to the real working environment. During the consulting intervention participants may be involved in a number of learning activities, but it is essential to ensure that this learned knowledge to the business.

\section{Management consulting}

In developed market economies consulting organizations to specialize its services based more on specialization of its clients. The oldest form of specialization was the following functional principle (Mihailović, 2011). This means that the consultants specialize in one of the control functions (production management, finance, marketing, ...).

Over time, the importance of specialization received by sectors: banking, small business, transportation, construction, etc. (Blečić, 2005). Consulting organizations 
of Serbia is mostly organized on a functional basis, or insufficient specialization in individual sectors. This is evident if observed offer consulting organization that focuses on business issues of particular functions of the companies clients. Consequently, the development of consulting services in Serbia is in its initial phase, which is similar to the beginnings of consulting services in developed economies.

\section{The regulatory and institutional factors of development of management consulting in Serbia}

Given the current trends in the consulting countries of our region, as well as the degree of development of guidelines consulting with EU countries, the market for consultancy services in Serbia has not been significantly developed in the past. Owners and managers of companies are still not enough to feel the need for external services, which would solve business problems. Bearing in mind the level and quality of demand, not offer consulting services has not reached the required level. In such circumstances, donor assistance in the past has significantly been given to promotion of conditions for the development of this market. Specifically, within the EU "Non-financial support for the development of SMEs sector in Serbia", in 2002-2004. year made significant steps in the creation and strengthening of the training and consultancy services in the Republic of Serbia. This project is through a network of republican / regional agencies for the development of SMEs (small and medium enterprises and entrepreneurs) conducted 820 training programs for future entrepreneurs and owners of SMEs, in line with the recommendations and suggestions of the analysis of training needs. Also, in the previous phase of this project have been identified as available local resources that are able to provide adequate training and consultancy services in various areas (realized basic training for coaches and executed process akreditecije service "providers"). Having regarded with the underdevelopment of the market of consulting and training services in the Republic of Serbia, especially outside Belgrade, in the framework of this project is not realized and the Scheme to encourage education and consulting (Service Support Scheme - SSS). The main objectives of "SSS", in whose implementation involved 7 regional agencies / centers to support SMEs with service providers as subcontractors, were providing access to existing and potential entrepreneurs with quality consulting services (mostly assistance in developing a business plan) and training at affordable (subsidized ) prices, as well as the realization of smaller regional projects of importance for the development of SMEs. Realization of SSS was aimed to strengthen the role of regional SME agencies as a catalyst of entrepreneurial development and market development consulting services for SMEs in Serbia in joining the European Union.

In countries that joined the EU observed the three prevailing trends: (1) the convergence of economic and social systems to EU standards, (2) economic development and (3) development of the sector of consultancy services. Comparative analysis of the consulting market in Central and Eastern Europe suggests that there is a significant correlation between the rate of growth of the consulting market and the growth rate of gross domestic product (GDP). In fact, in all the countries that have had positive growth rates of GDP from $3.7 \%$ to $8.1 \%$. recorded positive growth rates of consultancy market from $4 \%$ to $35 \%$ (International Management Consulting, 2006). The average growth rate 
of consultancy markets in the analyzed countries in 2004 amounted to $15.17 \%$, while the average growth rate of GDP was $5.08 \%$. Consequently, in these countries the sector consulting at the rate of growth is running ahead of the general economic development and at the same time on it retroactive effect. Today, no advanced market economy can not be imagined without consulting a superior. However, in Serbia, institutional and infrastructural factors are still the "bottleneck" of market development consulting services (Mihailović, Cvijanovic, 2011).

Based on the results of empirical research (Mihailović, 2011), we can conclude the following: The three most important factors of the development of consulting services are: education and information, development projects and affirmation of market economy. the greatest impact on the development of consulting services in Serbia are those variables that, following their nature, might call education and information. This shows that Serbian companies not well informed for the role and significance of consulting services have that training as personnel, in this sense, is not enough. This observation clearly indicates when you need to focus primarily and consulting organizations and companies that use consulting, but also the state, because of improvements to education and awareness in this area had all the advantages: consulting organization would put more jobs (and therefore more money, to intensify its development); the company would, using the services of consulting organizations, significantly accelerated their development and improve performance; the state would, if nothing else, get richer sources of budget financing.

\section{Capacity building for non-financial support to enterprises and entrepreneurs and development consultancy services}

In the local public consulting services usually include assistance in drafting a business plan, which is used when applying for a loan, or approximate training for potential entrepreneurs. Entrepreneurs in starting and developing their own business, it is necessary to help, primarily in the form of non-financial support to their businesses grew and remained on the market in transitional conditions (Cvijanovic, Mihailovic, Simonovic, 2009). It reflects the consulting services providing information, consultation, mentoring, training and training in different fields of importance to conduct business. Entrepreneurs who start independent operations generally have no experience in the management and running of the company and do not have formal education in this field. In such conditions, assistance and support during the initial period can significantly increase their chances of success. In the future it is necessary to continue to support the development of various forms of consulting services for the SME sector by public, private and NGO (non-governmental organization) sector, in cooperation with donors.

According to the traditional approach, the implementation of the program of state aid in the field of non-financial supports to the development of the SME sector takes place through the established dedicated regional and local agencies. Used as direct state intervention in the form of organization, in order to compensate for the lack of these services in the local market and at subsidized prices or free of charge for users, which, unfortunately, has not proved to be a long term cost effective solution. In practice, such organized services of non-financial support mostly, in the opinion of users, overly 
generalized, unadjusted real needs and generally of poor quality, the ability to hamper the development of local private supply and increase the cost of services.

Modern approach to non-financial support to small and medium-sized enterprises based on the principle of building a private local service market for business development that meets the needs and capacity to pay small businesses, in order to create long-term sustainable, market solution. State intervention in the form of subsidies on the demand side, in the transitional period shall be used for the implementation / privatization of trusted programs that were previously implemented local agencies from the public sector, by private consultants and capacity building service providers (Paraušić, Cvijanovic, Mihailovic, 2007). On the supply side are used grants and vouchers, which are parts from entrepreneurs to them, according to their own needs, seize to cover part of the cost of services of private consultants. The role of local development agencies is gradually shifting from the provision of specific services to help connect entrepreneurs with private bidders for these services, improving the offer, the range and quality of services for business development in a particular territory and strengthen awareness of entrepreneurs about their own needs and the importance of these services. Development of the market of consulting services is not a simple or easy task that can be accomplished in a short period and with modest financial contribution to the country. Local private consulting sector often lacks not only an interest in this area, but the real capacities, and entrepreneurs are willing to spend their time and money only to services from which they can see direct benefits in a very short period of time. In such circumstances, private market these services can hardly be generated independently. At the same time, it is unrealistic to expect that a whole range of services for business development can be implemented on a commercial basis, without the intervention of the state, as part of the services, especially those aimed at start-ups, are not sufficiently profitable.

\section{Conclusion}

In Serbia, since 2000, the consultancy has become very topical. Demand for consulting services is growing with the objective needs and dictates them: privatization, valuation of companies, establishment of new small and medium enterprises as a prerequisite of faster development of the market economy, new products, the search for new markets, etc... Serbia, for objective and subjective reasons, is late with the transition, and, in order to catch up with other countries, rapidly privatize public property, often clumsily, sometimes inadequately controlled and under, to put it mildly, unclear circumstances. Following the effect of these processes is inevitably rapid development consulting services. It is natural that the advice be similar to what happens in the economy: an intense, aggressive, almost uncontrolled, so no wonder it is often the vulgarized.

Accordingly an initiated economic reform, development of the market of consulting services is directly dependent on the current process of transition and restructuring of domestic companies. At the same time, the elimination of external constraints and the return to Serbia into international economic flows caused a significant increase in demand for new knowledge, experience and expertise, including those in the form of consultancy services. Particular interest is related to the programs of rehabilitation and restructuring of enterprises, but also in the formulation and implementation of development strategies 
and networking with economic actors on the international market, the introduction to information technology, improving the performance of the basic functions of management companies, joint ventures, technological cooperation and others. The privatization of the company requires a lot of knowledge and creativity, which is a significant area of consulting organizations. The introduction to market business with a company in Serbia represents a stimulus for consultants to expand the range of consultancy services, especially as the clients must be prepared to the rational use of internal and external professional and creative potential.

\section{References}

Blečić, S. (2005): Međunarodna trgovina konsalting uslugama, magistarski rad, Ekonomski fakultet, Beograd.

Bols, H. R. (1971): "Korišćenje eksternih usluga menadžment konsaltinga", Međuregionalni seminar za poboljšanje usluga menadžment konsaltinga (Kopenhagen, Danska). Prvi tom: Izveštaj seminara i tehnički radovi, Njujork, Ujedinjene Nacije.

Crager, J., Lemons, D. (2003): Measuring the Impact of Knowledge Management, American Productivity and Quality Center.

Cvijanović, D., Mihailović, B., Simonović, Z. (2009): “Tranzicija u Srbiji: efekti i ograničenja“, „Tranzicija“ Ekonomski institut Tuzla, JCEA Zagreb, DAEB, Institut za ekonomiku poljoprivrede Beograd, feam Bukurest; br. 21-22/2008, str. 87-100.

Engwall, L., Kipping, M. (2003): Introduction: Management Consulting as a Knowledge Industry, in: Kipping, Engwall (2003).

Gajić, B. (2004): "Integrisani savremeni sistemi za merenje performansi preduzeća", Ekonomski anali, broj 161, april - jun 2004., str. 151-164.

Guide to membership, Institute of Management Consultants, London, 1974.

Heuermann, R., Herrmann, F. (2003): Unternehmensberatung. Anatomie und Perspektiven einer Dienstleistungselite, München: Verlag Franz Vahlen.

Janićijević, N. (1992): "Uloga konsultanata u organizacionim promenama i razvoju“", Zbornik radova: Privredni sistem i efikasnost poslovanja preduzeća u uslovima svojinske transformacije, Univerzitet u Nišu, Niš.

Kubr, M. (1976): Management consulting - A guide to the profession, International Labour Office, Geneva

Mihailović, B. (2007): Uloga konsaltinga u restrukturiranju preduzeća u tranziciji, monografija, Institut za ekonomiku poljoprivrede, Beograd.

Mihailović, B. (2011): Razvoj konsultantskih usluga u Srbiji $i$ njihov uticaj na performanse preduzeća u agrokompleksu, monografija, Institut za ekonomiku poljoprivrede Beograd.

Mihailović, B., Cvijanović D. (2011): “Organizacije za pružanje konsultantskih usluga u Srbiji”, Ekonomika poljoprivrede 2011 (58) 4, Naučno društvo agrarnih ekonomista Balkana, str. 711-721. 
Paraušić, V., Cvijanović, D., Mihailović, B. (2007): “Institucionalne i infrastrukturne barijere uspešne primene agrarne politike Srbije u 2008. godini”, Rad saopšten na naučnom skupu: »Agrarna $i$ ruralna poltika u Srbiji: reforme u periodu tranzicije i predlog mera za 2008. godinu« i objavljen u zborniku radova (redaktori Danilo Tomić, Miladin M. Ševarlić). Društvo agrarnih ekonomista Srbije DAES, Poljoprivredni fakultet, Zemun, septembar 2007; str. 99-111;

Philips, J. (2000): The consultant's scorecard: tracking results and bottom-line impact of consulting projects, McGraw-Hill Companies, Inc.

Vodič Međunarodne organizacije rada (ILO) za profesiju menadžment konsaltinga// Retrieved Novembar 18, 2016, from www.ilo.org 